\title{
The Relationship Between Instagram Social Media Intensity and Consumptive Behavior of Fashion Products Among Early Adulthood Women
}

\author{
Nabila Putri Sabrina ${ }^{1}$ Sandi Kartasasmita ${ }^{1^{*}}$ \\ ${ }^{1}$ Faculty of Psychology, Universitas Tarumanagara, West Jakarta, Indonesia \\ *Corresponding Author. Email: sandik@fpsi.untar.ac.id
}

\begin{abstract}
This study aims to see whether there is a relationship between the intensity of the use of Instagram social media and the consumptive behavior of fashion products in early adulthood. The method used in this study uses a quantitative approach with a correlation to answer the relationship between variables. The sample used is non-probability sampling with a purposive sampling method. Data dissemination is done online via google form. This study involved 381 female respondents in the age range of 20 to 30 years, individuals who are active users of Instagram social media and individuals who have income either allowance or salary. Data processing in this study uses the SPSS for Windows version 20.0.0 program. Tests conducted using nonparametric Spearman's Rho technique because based on the results of the normality test the data distribution is abnormal. The results of this study state that there is no significant relationship between the intensity of the use of Instagram social media with the consumptive behavior of fashion products on early adult woman, with a value of $\mathrm{R}=0.085$ and $\mathrm{P}=0.96$.
\end{abstract}

Keywords: consumptive behavior, instagram, fashion, early adult women

\section{INTRODUCTION}

The use of technology and information is increasing rapidly at this time. The emergence of the Internet was the beginning of the development of social media. Through the internet, the public is made easier to obtain the information needed. The presence of the internet in the 1990s supported the development of digital communication and information. So that until now the digital world has become a new lifestyle in the world, including in Indonesia. Data reported by APJII [1] (Indonesian Internet Network User Association) in 2018 stated that Indonesia has a population of 264.16, of which 171.7 million people are internet users, and continues to increase compared to the previous year. The largest is Java Island with the highest internet users compared to other islands. West Java is $16.6 \%$ superior as the highest internet user compared to Central Java and East Java (APJII, 2019). Social networking sites or social media are places where everyone can communicate with each other without having to meet. Social media provides a platform whereas people can exchange and get information from various parts of the world. The emergence of social media makes people see the various activities of other people, even though they have never met or even know each other [2]. Communicating on this application-based technology has a wide variety of variations, the best known of which are Facebook, Whatsapp, Twitter, Instagram, Line and so on
Zarella [3] also states that social media has become a new media paradigm in the marketing industry.

Social media also describes their respective partners, each social media has a corresponding content and content. Instagram is one of the most commonly used social media applications. Its existence attracts the attention of all people. Not surprisingly, this platform is also one of the most influential social media applications in life. Its users are very diverse, ranging from adults, parents, adolescents, to children. The main function of Instagram is to provide facilities for its users to post visual content in the form of photos or videos. As identified, image-based social media is becoming increasingly popular among young users, especially adolescents and young adults [4]. Research from NapoleonCat [5] notes that in January 2020 there were $62,230,000$ million people in Indonesia using Instagram, which is $22.7 \%$ of the entire population. The majority of users are women $(51 \%)$ with the largest group aged 18 to 24 years or around 23,000,000 million people. This age is the transitional age from adolescence to adulthood or referred to as early adulthood. This age is a period where individuals develop themselves by establishing broader social relationships. This need is useful for exchanging information, sharing experiences, or collaborating on certain projects or plans [6]. In their early adulthood, they are the generation where they grew up in the era of internet and digital advancement. Women at this stage are also individuals who tend to follow fashion and 
pay attention to their [7]. In modest dress, the early adult stages emphasize clothing as a status symbol [8].

In this early adulthood, individuals are usually economically independent, which can encourage individuals to behave consumptively [9]. This consumptive behavior can lead to a consumerist lifestyle [10]. Consumerism is the notion of consumptive life, so it can be said that people who have consumptive behavior no longer consider the use and function of an item, but rather consider the prestige inherent in that person [11]. This kind of consumption has become a culture that develops rapidly in everyday life, because the practice of consumer hedonism is very prevalent in modern society today.

Initially, the function of purchasing behavior was to fulfill primary and secondary needs. With the increasing number of products and increasing types, now the consumption is gradually changing into a consumption culture [12]. Clothing is one of the needs of each individual. One of the causes of consumer behavior in this era is fashion. Fashion is a reflection of the unique social, cultural and environmental cycles at certain times in certain environments and also that is important in one's personal image [13]. Fashion is also an object that is full of images and lifestyles, individuals wear clothes not only because of their use values [14]. She also revealed that the choice of clothes for women tends to have very diverse types and models.

The ease of access and diversity that exists on Instagram makes its users able to get bad influence. The emergence of fashion in this era is increasingly developing coupled with the expanding media so that fashion has its own trend, especially on Instagram. The presence of this platform has a strong influence on the development of fashion, ranging from trends in branded goods, luxury retail, clothing, and beauty [15]. The function of clothing is no longer a body protector, the development of this era has made clothing a lifestyle and trend [16]. As consumers, the large number of product choices makes them willing to spend their money to keep up with current innovations and trends, coupled with a strong aesthetic preference (17). Fromm [18] also states that humans no longer see the value in consuming goods. This phenomenon can continue to develop, due to factors that can lead to consumer behavior, one of which is lifestyle [19]. To increase self-esteem and social status, it is usually what makes individuals engage in consumptive behavior. Based on the background described, researchers are interested in further reviewing whether there is an influence of Instagram social media on the consumptive behavior of fashion products, especially in early adulthood.

\subsection{Formulation of the Problem}

Is there a relationship between the intensity of the use of Instagram social media and the consumptive behavior of fashion products in early adulthood women?

\subsection{Research Purposes}

To find out whether there is a relationship between the intensity of the use of Instagram social media and the consumptive behavior of fashion products in early adulthood women.

\subsection{Research Hypothesis}

$\mathrm{H}_{0}$ : There is no relationship between the intensity of the use of Instagram social media on the consumptive behavior of fashion products in early adulthood women. $\mathrm{H}_{1}$ : There is a relationship between the intensity of the use of Instagram social media on the consumptive behavior of fashion products in early adulthood women.

\section{THEORY}

\subsection{Consumptive Behavior}

Lubis [12] explains that consumptive behavior is not sourced by rational thinking, but it desire don't reach irrational levels anymore. Individuals with behaviour inherent consumption, the need is no longer based on factors needs, but already based on the factor of desire (want).

Fromm [18] explained that consumptive behavior is divided into several dimensions, namely as follows: (1) Fulfillment of wishes, each people will never stop feeling satisfied at some point, even tends to develop. Based on this thing, when someone consuming something, the individual will always hope to get more satisfaction to achieve its own satisfaction, even though the goods is not really needed, but it will still be done. (2) Goods out of reach, when individuals consume, their behavior changes being compulsive and unreasonable. When this happens, the individual feels himself is "incomplete" and will seek supreme satisfaction with acquire new products. Individuals will no longer seek their own needs and the goods for himself; (3) Non-productive goods, if consumption of goods becomes too much, consumption becomes not clear, and the goods become unproductive for individuals; (4) Status, individuals can be said to have consumptive behavior if they have excessive items due to status considerations. This behaviour is no longer a meaningful, humane, and useful experience, because only done to satisfy his desire for status.

Characteristics of consumptive behavior according to Sumartono [12], namely: (a) Buying goods because of a special offer; (b) Purchasing goods because of its attractive appearance; (c) Purchasing for the sake of personal appearance and prestige; (d) Purchasing products based on high or low price considerations (not on the basis of benefits or uses); (e) Purchasing goods that are deemed able to maintain social status; (f) The influence of advertising / models that promote goods; (g) The emergence of self-confidence high when buying expensive items; (h) Purchasing two or more products one of a kind. 
Fransisca \& Suyasa [20] explain the impact of behavior consumptive as follows: (a) Causing waste, this happens because buying behavior is only to fulfill momentary pleasure not meet real needs. Buying stuff is an excuse to follow fads and desires. Funds that should be used to buy items that are needed but used for goods that are useless and can lead to cost inefficiencies; (b) Causing anxiety, consumptive behavior can cause individuals to feel anxious because he felt the need to buy the item he wanted even though useless. Purchases without financial support can result worry. Insecurity caused by consumer behaviour is a situation of excessive purchases of goods by individuals. Impact consumptive behavior is also stated by Irmasari (2010) that Behavior consumers can cause social jealousy, reduce saving opportunities, and often not paying attention to future needs.

\subsection{Instagram Intensity}

Intensity in the Kamus Besar Bahasa Indonesia (KBBI) [21] expressed as "a measure of intensity or state of rank". Horrigan [22] explains that there are two basic aspects to the intensity of a person's internet usage need to be careful, namely how often they use the Internet and how long they use each time they visit the Internet. Intensity can be said as a form of attention and interest based on the quality and quantity determined by the individual (Santrock, 2006). Tubb \& Moss [23] intensity can be viewed from the duration spent by an individual while doing an activity and the frequency with which it is performed. According to Casdari [24], three factors influence intensity the use of social media is the following: (1) Internal needs factors, this factor is related to human psychological needs. One of them is the closeness of the relationship with other people or strangers (relatedness); (2) Social motive factors, namely factors that are influenced by the environment or people another, one of which is the integration of individuals with friends or groups; (3) Emotional factors, emotions can change the intensity of media use social. If social media makes the individual feel happy, individual it will repeat the activity using the social media. Individuals who frequently visit Instagram social media have a background by social motivation, such as hoping to be recognized and appreciated by the environment.

\section{METHOD}

\subsection{Research Participants}

This study took a sample of 381 people. Research subjects in this study have several criteria that must be fulfilled. The first criterion is individuals aged 20 to 30 years and, female sex. The second criteria is that individuals are active users of Instagram social media. And the third criterion is that individuals have an income, either pocket money or salary. The sample in this study used nonprobability sampling and purposive sampling method.

\subsection{Types of Research}

This research is a non-experimental quantitative research. This research is a correlational research, which describes the relationship between the intensity of playing Instagram social media and the consumptive behavior of fashion products in early adulthood. Based on this formula, there are two variables in this study. This research wants to describe the relationship between the intensity of playing Instagram social media with consumptive behavior.

\subsection{Measuring instrument}

Researchers provide two scales, namely the intensity scale of Instagram use taken and compiled in the Sukmaraga thesis which is based on the aspect of frequency and duration consisting of 4 items with answers consisting of a range of 5 multiple choice points and a consumptive behavior scale taken and compiled in the Amalia thesis which is based on the consumptive behavior aspect of Sumartono [12], then adapted by the researcher so that it fits the topic that researcher want to measure. This measuring instrument has 31 items consisting of 15 favorabel items and 16 unfavorable items.

\subsection{Processing and Data Analysis Techniques}

The data that has been obtained from the questionnaire will be analysed quantitatively. The data that has been obtained are then input and processed using the Statistical Package for Social Science (SPSS) calculations, namely parametric statistical analysis to determine the basis of a goal data distribution, namely the relationship between the intensity of the use of Instagram social media on consumptive behavior. Testing the reliability of measuring instruments in research This is done with the help of the SPSS program version 20.0.0 with the Alpha Cronbach coefficient by dividing the items by the number the item. Testing and data analysis conducted is a reliability test a tool to measure Instagram's social media usage intensity and consumptive behavior, descriptive test of research subjects based on control data, test descriptive research data, as well as data normality test in this study using the Kolmogorov-Smirnov test. Main data analysis in research namely the correlation test used to determine the relationship between variables research. The correlation test used was Spearman's Rho non-parametric test because based on the results of the normality test, it was stated that the data was not normally distributed. Meanwhile, to analyze data additionally used correlation test between variables one with other variable dimensions. Different tests were also carried out as additional data analysis to test variables and control data of research subjects using Kurskal-Wallis. Based on these results, the researchers then discussed the results analysis. Furthermore, the researcher makes the results of the discussion and makes research conclusions. 


\section{RESULT AND DISCUSSION}

The test results based on the correlation results found that there was no relationship between the intensity of using Instagram social media and consumptive behavior with a correlation value of $r=0.085$ and a significance value of $p$ $=0.096$. So that the higher the intensity of using Instagram social media, the lower the consumptive behavior. Likewise, vice versa, the lower the intensity of Instagram social media use, the higher the level of consumptive behavior. Based on the results of the data analysis that has been done, it shows that there is no relationship between the intensity of social media use and consumptive behavior. These results support research from Caroline (2019) who also saw the influence of the intensity of the use of Instagram social media on consumptive behavior. That there were negative results in her research. Then there are also many other factors that can influence consumptive behavior, according to Setiadi (2010) there are several factors that influence consumptive behavior, such as cultural factors (including groups, family, and social roles and status), as well as psychological factors, namely motivation, perception, experience, and attitudes and beliefs. The results of obtaining data from subjects who participated in the study were individuals aged 20 to 30 years, most of whom were college students. So that the researchers assess that they do not have their own income and still rely on money from their parents, so that it can allow low consumptive behavior. Moningka \& Adiputra [16] in their research also argue that the buying process begins with recognizing their needs, that is, the buyer recognizes a problem or need. So that the situation and conditions that are being experienced can affect purchasing behavior. With a condition where according to him other needs are more important.

The results of the analysis of this study reject the results of research conducted by Rahma, in her research it has the results that there is a relationship between the intensity of the use of Instagram social media and consumptive behavior among students of SMA Muhammadiyah 1 Magelang City. There are several reasons for the differences in the results of these studies. First, there are differences in the intended subjects, Rahma's research uses high school student subjects, while the research subjects are early adult individuals. This allows age to have an effect on research results. Second, there are differences in measuring instruments and aspects used to measure the intensity variable of using social media Instagram. Rahma's research uses 4 aspects, namely attention, appreciation, duration and frequency. Meanwhile, researchers only use 2 aspects, namely frequency and duration. Third, there are differences in measuring instruments and aspects used to measure consumptive behavior variables. Rahma's research uses 3 aspects, namely impulsive buying, non-rational buying, and wastafel buying. Meanwhile, researchers used 8 aspects developed by Sumartono [12], namely buying goods because of the lure of gifts, buying goods to maintain one's appearance and prestige, buying things on the basis of high or low price considerations (not on the basis of their benefits and uses), buying goods only to maintain status symbol, wearing goods because there is an element of conformity to the model that advertises products, the emergence of an assessment that buying something at a high price will lead to high self-confidence, and trying more than two similar products (different brands). So that it can be said that each item used must be different and it allows the way of scoring in each aspect is different by giving a score on the measuring instrument used by the researcher. Fourth, the number of subjects carried out in the study included both men and women, while researchers only examined individual women. So that the population results obtained can affect the results of the study.

\section{CONCLUSION}

Based on the data analysis regarding the results of the correlation test of the intensity of the use of Instagram social media with consumptive behavior in early adulthood using Instagram, the results of the correlation are $r=0.085$ with a significance value of $\mathrm{p}=0.096$. These results indicate that there is no significant relationship between the intensity variable of using Instagram social media and consumptive behavior. The higher the intensity of the use of Instagram social media, the lower the consumptive behavior, and vice versa. This shows that the intensity of Instagram social media use has no relationship with consumptive behavior. Thus, the results of this study reject $\mathrm{H}_{1}$ and accept $\mathrm{H}_{0}$.

The shortcomings and limitations of this study are related to the distribution of the research sample, especially the distribution of age, occupation, income, and matters related to research variables which have unequal or uneven sample distributions, so it is not possible to summarize the results of the study. The data collection process is done using a questionnaire method, where sometimes data collection is done through a questionnaire can make the subject do not give an appropriate opinion. This can be based on differences in understanding, thoughts, situations being experienced, and honesty in filling out the questionnaire. Then there are limitations in the selection of measuring instruments, where the researcher only adapts the measuring instrument through the thesis and there are some items that are not reliable when used so that it is necessary to revise or retest the measuring instrument items so that they can be used for all research samples.

Researcher's suggestion for the next research is by expanding the scope, such as adding other factors and mediators in research that can influence early adult consumptive behavior, such as culture, perceptions, etc. As well as perfecting the measuring instrument used, in order to get accurate results by adding other variable aspects.

The practical suggestions from this research for readers are expected to be used as a source of knowledge and knowledge regarding the intensity of using Instagram social media and consumptive behavior in early adult women. For women who have a tendency to consumptive 
behavior, it is hoped that they can control themselves, change, and reduce or eliminate these habits.

\section{REFERENCES}

[1] APJII. (2016). Profil Pengguna Internet Indonesia 2016. Jakarta: Asosiasi Penyelenggara Jasa Internet Indonesia. https://apjii.or.id/content/read/39/264/SurveiInternet-APJII-2016.

[2] Mulawarman, \& Nurfitri, A. D. (2017). Perilaku pengguna media sosial beserta implikasinya ditinjau dari perspektif psikologi sosial terapan. Buletin Psikologi, 25(1), 36-44. https://doi.org/10.22146/buletinpsikologi. 22759

[3] Zarella. (2010). The social media marketing book. Oreilly Media: USA.

[4] Trifiro (2018). Instagram Use and It's Effect on WellBeing and Self-Esteem.

[5] Napoleon Cat. (2020, October 6). Instagram users in Indonesia. https://napoleoncat.com/stats/instagram-usersin-indonesia/2020/01

[6] Maheswari, J. \& Dwiutari, L. (2013). Pola perilaku dewasa muda yang kecendrungan kecanduan situs jejaring sosial. Jurnal Penelitian dan Pengukuran Psikologi, 2(1). https://doi.org/10.21009/JPPP.011.02

[7] Clow, K. E. \& Baack, D. (2002). Integrated advertising, promotion, and marketing communications. NJ: Prentice-Hall.

[8] Kustriani. (1997). Measuring customer satisfaction with service quality using american customer satisfaction model (ACSI Model). International Journal of Academic Research in Business and Social Sciences, 1 (3).

[9] Zikra, R dan Yusra, Z. 2016. Kepuasan Wanita Berbelanja Produk Fashion Berdasarkan Cara Membeli. Jurnal RAP UNP, 7(1), 55-66. https://doi.org/10.24036/ rapun.v7i1.6608

[10] Hidayatun, U. (2015) Pengaruh intensitas penggunaan media sosial dan dukungan teman sebaya terhadap perilaku konsumtif pada siswa kelas XI SMA Muhammadiyah 3 Yogyakarta tahun pelajaran 2014/2015. Jurnal Riset Mahasiswa Bimbingan dan Konseling, 4(10). http://journal.student.uny.ac.id/ojs/index.php/fipbk/article/ view/269

[11] Tiurma, Y. S. (2009). Hubungan antara Perilaku Konsumtif dengan Body Image pada Remaja Puteri. Skripsi. Fakultas Psikologi-Universitas Sumatera Utara.
[12] Sumartono. (2002). Terperangkap dalam iklan. Bandung: CV Alfabeta.

[13] Azuma, N. \& Fernie, J. (2003). Fashion in the globalised world and the role of virtual networks in intrinsic fashion design. Journal of Fashion Marketing and Management, 7(4), 413-427. Bakewell, C. and Mi.

[14] Yusra, Z \& Zikra, R. (2016). Kepuasan wanita berbelanja produk fashion berdasarkan cara Memmbeli. Jurnal RAP, 7(1), 55-56.

[15] Ha, Y., Kwon, S., Cha, M., \& Joo, J. (2017). Fashion conversation data on instagram. https://arxiv.org/abs/ 1704.04137

[16] Adiputra, R., \& Moningka, C. (2012). Gambaran Perilaku Konsumtif Terhadap Sepatu Pada Perempuan Dewasa Awal. 5(2), 15. https://journal.ubm.ac.id/index. php/psibernetika/article/view/536

[17] Wood, B. E. (2013). What is a social inquiry? Crafting questions that lead to deeper knowledge about society and citizenship participation. SET: Research information for teachers, 2013(3), 20-28. https://doi.org/ 10.18296/set.0334. 2013. 20-28.

[18] Fromm, E. (1995). The sane society. New York: Reinhart

[19] Anggraini, R. \& Santhoso, F. H. (2019). Hubungan antara gaya hidup hedonis dengan perilaku konsumtif pada remaja. Gadjah Mada Journal of Psychology (GamaJoP), 3(131). 10.22146/gamajop.44104

[20] Fransisca, \& Suyasa, P. T. (2005). Perbandingan perilaku konsumtif berdasarkan metode pembayaran Jurnal Phronesis, 7(2), 172-199. https://www. researchgate.net/publication/319751850_Perbandingan_Pe rilaku_Konsumtif_berdasarkan_Metode_Pembayaran

[21] KBBI, 2016. Kamus Besar Bahasa Indonesia (KBBI). [Online] Available at: http://kbbi.web.id/pusat

[22] Novianto, L. (2006). Perilaku penggunaan internet di kalangan mahasiswa (Studi deskriptif tentang perilaku penggunaan internet dikalangan mahasiswa perguruan tinggi negeri (FISIP UNAIR) dengan perguruan tinggi swasta (FISIP UPN) untuk memenuhi kebutuhannya).

[23] Nurjan, S., Tjahjono, H. K., \& Yamin, M. N. (2016) Trends in the adolescent delinquency bchavior at the Institute of Islamic Education Ponorogo District. Journal of Government and Politics.

[24] Casdari. (2006). Peranan Motivasi Berprestasi Terhadap Prestasi Kerja Pada Agen Yang Bekerja di Kantor Operasional Pondok Gede dan Kalimalang Ajb Bumiputera 1912 Cabang Jakarta. Skripsi (tidak dipublikasikan). UI: Jakarta. 